\title{
OPEN
}

\section{Author Correction: Impediometric Electrochemical Sensor Based on The Inspiration of Carnation Italian Ringspot Virus Structure to Detect an Attommolar of miR}

\section{E. Ghazizadeh, Seyyed Ebrahim Moosavifard, Negin Daneshmand \& Saeid kamari Kaverlavani}

Correction to: Scientific Reports https://doi.org/10.1038/s41598-020-66393-z, published online 15 June 2020

The original version of this Article contained errors in Affiliations 2 and 3, which were incorrectly given as 'Department of Advanced Medical Sciences \& Technologies, School of Medicine, Jahrom University of Medical Sciences (JUMS), Jahrom, 74148-46199, Iran' and 'Research Center for Noncommunicable Diseases, School of Medicine, Jahrom University of Medical Sciences (JUMS), Jahrom, 74148-46199, Iran’, respectively.

The correct affiliations are listed below:

Affiliation 2

Department of Advanced Medical Sciences \& Technologies, School of Medicine, Jahrom University of Medical Sciences, Jahrom, 74148-46199, Iran.

\section{Affiliation 3}

Research Center for Noncommunicable Diseases, School of Medicine, Jahrom University of Medical Sciences, Jahrom, 74148-46199, Iran.

Additionally, in the Supplementary Information file originally published with this Article, Negin Daneshmand was omitted from the author list. Furthermore, the email address of E. Ghazizadeh was omitted.

These errors have now been corrected in the HTML and the PDF versions of the Article and in the accompanying Supplementary Information.

\footnotetext{
Open Access This article is licensed under a Creative Commons Attribution 4.0 International License, which permits use, sharing, adaptation, distribution and reproduction in any medium or format, as long as you give appropriate credit to the original author(s) and the source, provide a link to the Creative Commons license, and indicate if changes were made. The images or other third party material in this article are included in the article's Creative Commons license, unless indicated otherwise in a credit line to the material. If material is not included in the article's Creative Commons license and your intended use is not permitted by statutory regulation or exceeds the permitted use, you will need to obtain permission directly from the copyright holder. To view a copy of this license, visit http://creativecommons.org/licenses/by/4.0/.
}

(C) The Author(s) 2020 